University of Texas Rio Grande Valley

ScholarWorks @ UTRGV

\title{
TRAMPLING, PEELING AND NIBBLING MUSSELS: AN \\ EXPERIMENTAL ASSESSMENT OF MECHANICAL AND \\ PREDATORY DAMAGE TO SHELLS OF MYTILUS TROSSULUS \\ (MOLLUSCA: MYTILIDAE)
}

Carlos E. Cintra-Buenrostro

The University of Texas Rio Grande Valley, carlos.cintra@utrgv.edu

Follow this and additional works at: https://scholarworks.utrgv.edu/eems_fac

Part of the Earth Sciences Commons, Environmental Sciences Commons, and the Marine Biology Commons

Recommended Citation

CARLOS E. CINTRA-BUENROSTRO "TRAMPLING, PEELING AND NIBBLING MUSSELS: AN EXPERIMENTAL ASSESSMENT OF MECHANICAL AND PREDATORY DAMAGE TO SHELLS OF MYTILUS TROSSULUS (MOLLUSCA: MYTILIDAE)," Journal of Shellfish Research 26(1), 221-231, (1 April 2007). https://doi.org/ 10.2983/0730-8000(2007)26[221:TPANMA]2.0.CO;2

This Article is brought to you for free and open access by the College of Sciences at ScholarWorks @ UTRGV. It has been accepted for inclusion in School of Earth, Environmental, and Marine Sciences Faculty Publications and Presentations by an authorized administrator of ScholarWorks @ UTRGV. For more information, please contact justin.white@utrgv.edu,william.flores01@utrgv.edu. 


\section{TRAMPLING, PEELING AND NIBBLING MUSSELS: AN EXPERIMENTAL ASSESSMENT OF MECHANICAL AND PREDATORY DAMAGE TO SHELLS OF MYTILUS TROSSULUS (MOLLUSCA: MYTILIDAE)}

\section{Author: CINTRA-BUENROSTRO, CARLOS E.}

Source: Journal of Shellfish Research, 26(1) : 221-231

Published By: National Shellfisheries Association

URL: https://doi.org/10.2983/07308000(2007)26[221:TPANMA]2.0.CO;2

BioOne Complete (complete.BioOne.org) is a full-text database of 200 subscribed and open-access titles in the biological, ecological, and environmental sciences published by nonprofit societies, associations, museums, institutions, and presses.

Your use of this PDF, the BioOne Complete website, and all posted and associated content indicates your acceptance of BioOne's Terms of Use, available at www.bioone.org/terms-of-use.

Usage of BioOne Complete content is strictly limited to personal, educational, and non - commercial use. Commercial inquiries or rights and permissions requests should be directed to the individual publisher as copyright holder.

BioOne sees sustainable scholarly publishing as an inherently collaborative enterprise connecting authors, nonprofit publishers, academic institutions, research libraries, and research funders in the common goal of maximizing access to critical research. 


\title{
TRAMPLING, PEELING AND NIBBLING MUSSELS: AN EXPERIMENTAL ASSESSMENT OF MECHANICAL AND PREDATORY DAMAGE TO SHELLS OF MYTILUS TROSSULUS (MOLLUSCA: MYTILIDAE)
}

\author{
CARLOS E. CINTRA-BUENROSTRO \\ Department of Geosciences, University of Arizona, Tucson, Arizona 85721
}

\begin{abstract}
Shell damage, if properly recognized, can provide information about biotic interactions between molluscs and their predators. However, it can be difficult to distinguish predatory damage from mechanical breakage, thus making interpretation of damaged modern and fossil shells problematic. To establish a clear-cut distinction between antemortem predatory crab damage and ante- and postmortem mechanical damage in Mytilus trossulus shells, a combined field and experimental approach was used. Mussels were exposed to predation by crabs, tumbled-live, tumbled-dead, and trampled. After $100 \mathrm{~h}$ of tumbling, live-collected mussel shells were abraded and disarticulated but not otherwise damaged. Eight percent of the dead-collected shells were broken during tumbling. There was a proportional (length, width, and thickness) size reduction in both tumbled-live and tumbled-dead shells after $100 \mathrm{~h}$. Breakage caused by crab predation under laboratory conditions was $\sim 19 \%$ of the prey offered. Three types of diagnostic damage were inflicted by crab predation: nibbles, nibbles and chips, and peels. Trampling and tumbling yielded three diagnostic breakage patterns: crescentic chips, angular chips, and slivered chips. Crushed shells and shells with fractured margins were caused by predation and trampling. Only twenty percent of the trampled-shells could be mistaken for preyed-upon shells. Only twenty-seven percent of the preyed-on shells could be mistaken for mechanicallydamaged shells. Overall, the source of damage could be correctly identified in $74 \%$ of the shells. Proper identification of crab predation in dead shells of this commercially important resource may prove valuable in studies of trophic interactions in modern environments. Inferring levels of crab predation, based on damage in fossil specimens, can be reliable if such analyses are calibrated by experimental studies of living representatives or analogs.
\end{abstract}

KEY WORDS: predation, crabs, mussels, brachyura, bivalves, tumbling, trampling

\section{INTRODUCTION}

This study focuses on the mussel Mytilus trossulus (Gould 1850), and its natural enemies, the crabs Hemigrapsus nudus (Dana 1851), H. oregonensis (Dana 1851), and Cancer oregonensis (Dana 1852). Using these organisms as a model system, the study combines experimental data and field observations to compare the biological damage caused by crabs with the mechanical damage caused by tumbling and trampling experiments.

Shell damage, if properly recognized, can provide information about biotic interactions between molluscs and their predators. The study of predator-prey interactions from fieldcollected empty shells of molluscs is an inexpensive and noninvasive strategy used by ecologists. Because of their potential damage to molluscan prey populations, including commercially important resources, the effect of durophagous (shell-breaking or eating) crabs on the populations of their victims becomes especially relevant. Some crabs that prey on molluscs typically attempt to gain access to the bivalve's tasty soft tissues by chipping and peeling at the growing edge of the shell, whereas others will attempt to crush the entire shell. To complicate matters, crabs and other peeling predators are known to switch to crushing, the effectiveness of which is dependent on the shell's strength relative to the strength of the crushing claw (see Boulding 1984, Zuschin et al. 2003). Successful chipping or peeling attacks can leave distinctive damage on the shell margin, whereas unsuccessful attacks are often repaired, leaving char-

Current address: Department of Environmental Sciences, The University of Texas at Brownsville and Texas Southmost College, Brownsville, TX 78520.

E-mail: carlos.cintrabuenrostro@utb.edu acteristic repair scars on the shell (Vermeij 1983a, Allmon et al. 1990, Alexander \& Dietl 2001).

Proper recognition of shell damage is even more important to paleoecologists who cannot make direct observations of predation but can often find shells preserved in the fossil record. Indeed, there is an impressive and diverse fossil record of predatory traces covering all periods of the Phanerozoic (Vermeij 1987, Kowalewski \& Kelley 2002, Kelley et al. 2003, Alexander \& Dietl 2005), which provide invaluable insights into past ecosystems. However, in cases other than predatory boreholes, it is often difficult to differentiate between "ante-and post-mortem" mechanical damage and "ante-mortem" predatory damage. Thus, it has proven difficult to attribute marginal shell damage in bivalves to predation by crustacean decapods, particularly crabs.

Identification of the cause of breakage is possible when the cause results in fragments with distinctive, source-dependant breakage patterns (Vermeij 1983a, 1983b, Cate \& Evans 1994, Zuschin et al. 2003). Peeled shells are diagnostic of crab predation (Lawton \& Hughes 1985). In contrast, crushed shells can be produced by other predators (including larger crabs, fishes, and birds) as well as rolling rocks (Vermeij 1983a, 1983b, Lawton \& Hughes 1985, Cadée 1994, Cate \& Evans 1994, Zuschin et al. 2003). Other distinctive types of damage to the bivalve shell can be produced during burrowing (Checa 1993).

Although a high percentage of shell fragments has been used to indicate high predation rates, their use to estimate predation pressure in fossil faunas is questionable because some predators leave either one (i.e., birds) or both valves (i.e., seastars) intact (Cadée 1994). Furthermore, the angular fragments produced by crushing predators can be degraded by subsequent physical abrasion (Cadée 1994), thus obscuring the true origin of the 
fragments (Oji et al. 2003). Once abrasion occurs, the resulting fragments from durophagous predation will be very similar to the ones produced by transportation or tumbling (Stanton \& Nelson 1980). Further useful reviews of shell-crushing are provided by Cate \& Evans (1994) and Zuschin et al. (2003).

Given the many difficulties encountered in distinguishing shell damage under natural conditions in the field or in the fossil record, a laboratory approach using controlled experiments can provide useful insights.

\section{METHODS}

\section{Specimen Collection}

Thirty individuals of the grapsid crab Hemigrapsus oregonensis, 10 individuals of $H$.nudus, and, 336 of the bivalve mussel Mytilus trossulus were collected during low tide at Argyle Creek, San Juan Island, WA, USA in July to August 2004. Argyle Creek is a unique pseudo-subtidal habitat between two saltwater systems: Argyle Lagoon and North Bay (Lazo 2004). The semidiurnal tidal regimen does not completely affect the Creek, and it remains covered by water even during the lowest low tide, providing predators with the opportunity to continue feeding throughout the entire tidal cycle.

In addition, xanthid and cancrid crabs were also collected: one individual of Lophopanopeus bellus (Stimpson, 1860), one Cancer productus Randall, 1839, and one C. oregonensis during low tide in False Bay, San Juan Island, WA and seven individuals of C. oregonensis and one Cancer magister (Dana, 1852), by dredging from $70-75 \mathrm{~m}$ at Rock Point $\left(48^{\circ} 29.52^{\prime} \mathrm{N}\right.$ and $122^{\circ} 56.97^{\prime} \mathrm{W}$ ), Lopez Island, WA.

A survey was conducted to estimate the population size of M. trossulus at Argyle Creek during low tide in July to August 2004. Sixteen quadrats, each $50 \times 50 \mathrm{~cm}$, were sampled in Argyle Creek. All live M. trossulus were counted in situ whereas all dead shells were collected for further analysis and counting in the laboratory. Because this study was conducted only for comparative purposes (see later), a rigorous assessment of temporal changes in the mussel population (i.e., variation through seasons and years) was not conducted.

\section{Laboratory Experiments}

All crabs and live-collected mussels were brought back to the laboratory and placed on seawater tables with continuously flowing water and salinity of $\sim 26 \%$. Prior to the experiments, all crabs were starved for $48 \mathrm{~h}$. Each crab was placed inside a 1 liter plastic beaker with meshed sides, which allowed proper identification of the crabs and their prey without any additional stress to the predator. The number of confounding factors (e.g., greater vs. smaller area available/crab) was also reduced with this approach. All crabs were males to avoid confounding effects between genders. All crab containers included cobbles from the collection area to mimic the natural environment and to reduce the stress level as much as possible. Pilot studies indicated that at least one individual from each of the crab species consumed a live-mussel with a smooth margin and nonabraded surface.

Mussel size classes were defined based on the size-frequency distribution of specimens previously obtained in the field. This practice served to distinguish if a particular mussel size was affected more than another by any of the experimental approaches. Three nonoverlapping size classes of mussels ( $\leq 20.6,21.2-34.6$, and $\geq 35.1 \mathrm{~mm}$ ), measured in terms of the maximum shell length, were used in the crab experiments. Carapace width and length were measured for each crab. Standard measurements (maximum shell length, width, and thickness) were taken for all mussels. Caliper precision was $\pm 0.01 \mathrm{~mm}$. One mussel of each size class was offered to each crab. Mussels were changed as soon as they were preyed on. Predation was monitored at least twice a day. All mussels used in the experiment lacked epibionts to prevent the opportunistic Hemigrapsus spp. from feeding on alternative prey.

A total of 336 mussels, with average maximum length and width of $20.8 \pm 0.6$ and $13.7 \pm 0.3 \mathrm{~mm}$, were offered to the crabs. Average maximum length per class ranged from 13.2-39.5 mm, whereas average maximum width ranged from $9.5-23.9 \mathrm{~mm}$ (Fig. 1).

There was no significant variation in the average maximum carapace width among the crab species (Fig. 2). Taxa represented by only one individual had the following maximum carapace widths: Lophopanopeus bellus $=29.7 \mathrm{~mm}$, Cancer productus $=50.6 \mathrm{~mm}$, and C. magister $=163 \mathrm{~mm}$.

To differentiate between ante and postmortem physical (e.g., wave action) damage and antemortem predatory damage, 30 live mussels (10/size class), with a smooth margin and nonabraded surface were used in a tumbling experiment. All specimens were measured and photographed, and then placed in a $750-\mathrm{mL}$ (10 cm diameter) tumbling barrel with $500-\mathrm{mL}$ of water and $\sim 130 \mathrm{~g}$ of sand and $\sim 130 \mathrm{~g}$ of gravel-to-cobble size sediments (collected from the same site as the mussels). The tumbling barrel was rotated at $53 \mathrm{rpm}$. Weight of the sediment and the weight of mussels $(\sim 130 \mathrm{~g})$ were both determined before the tumbling experiment was started. Balance precision was $0.01 \mathrm{~g}$. The shells were tumbled for $6 \mathrm{~min}, 1 \mathrm{~h}, 10 \mathrm{~h}$, and $100 \mathrm{~h}$. Given a tumbling barrel with a $10-\mathrm{cm}$ diameter and the rotation rate of $53 \mathrm{rpm}$, the tumbling speed approximates $530 \mathrm{~cm} / \mathrm{min}$. One hundred hours of tumbling is thus equivalent to $\sim 30 \mathrm{~km}$ of transport or in-place tumbling in the surf zone. After each of the four time periods used in the experiment, each shell was removed from the barrel, examined for damage to the shell margin, and photographed. All shells were returned to the tumbling barrel after each examination until the total of $100 \mathrm{~h}$ of tumbling was accomplished.

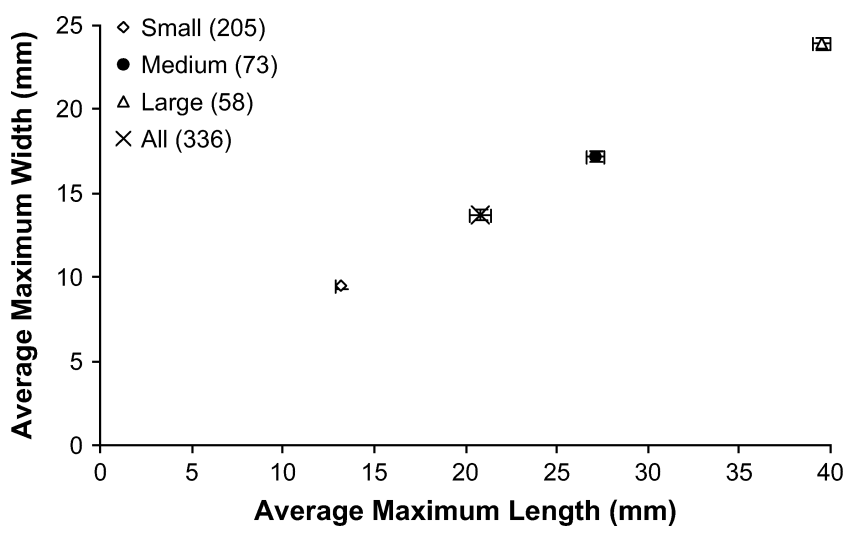

Figure 1. Mussel (Mytilus trossulus) average length versus width (mm) for all individuals, and within each size-class. Bars represent standard errors from the mean. Numbers of individuals for each category are in parentheses. 


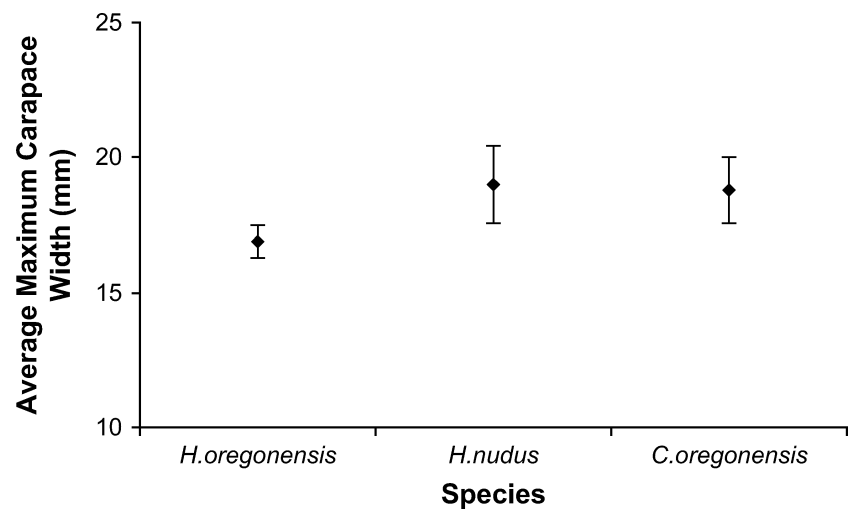

Figure 2. Crab maximum carapace width $(\mathrm{mm})$. Bars represent standard errors from the mean. Numbers of individuals for each taxa are: 30 Hemigrapsus oregonensis, 10 Hemigrapsus nudus, and 8 Cancer oregonensis.

Although as Cintra-Buenrostro et al. (2005) indicate, such an experimental design may not exactly duplicate the natural tumbling experienced by shells in the surf zone, the experiment provides some insight into the character of mechanical damage that can be generated at the shell margin by abiotic processes.

Tumbling experiments were repeated with dead-collected shells with nonabraded surfaces and smooth margins. Because variations in the weight of the experimental mussels occurred, the same proportion of shell, sand, and gravel-to-cobble size sediment was used as with the experiment with live-collected mussels. The number of mussel shells in each size class was the same in all experiments.

All shells collected from the field were counted, measured, and examined for the presence of any type of damage. Because Argyle Creek is an area heavily visited by tourists, bird watchers, researchers, and others, shell breakage may also be generated by people stepping-on the shells. To evaluate the nature of such anthropogenic shell breakage, 60 dead shells (20/size class) with smooth margins and nonabraded surfaces were stepped on thrice by the same person. Half of these trampling experiments involved shells placed on a sandy substrate, and the other half used a mixture of sand, gravel and cobbles (all sediment was collected in the Argyle Creek area).

The shape, length, and depth of shell damage that resulted from biological antemortem attacks by crabs, mechanical tumbling of live or dead shells, and mechanical crushing by trampling was visually compared. The number of shells showing damage and the number of instances that a particular damage occurred were recorded. A comparison between the damage patterns inflicted by different species of crab was not performed because not all crab species preyed on the mussels during the experiment, because some crab species were represented only by one or few individuals, and because only nine mussels were preyed upon by $H$. oregonensis. For the purpose of this study damage patterns inflicted by different crab species where combined.

\section{Statistical Analyses}

Preservational and methodological artifacts may cause bias in comparisons of live and dead molluscs. To reduce errors and increase statistical power, Cohen (1988) was followed to determine a minimum sample size $\left(n_{0.05[u 1 ; 1-\beta=0.8]}=12.3\right)$ of quadrats for the survey experiment using abundance data on the mussels collected during the pilot study. Three different quadrat sizes $(25 \times 25,50 \times 50$, and $100 \times 100 \mathrm{~cm})$ were also used during the pilot study. All mussels within the quadrat of each size were counted in situ, and the appropriate quadrat size was determined using Underwood (1997).

Rank correlation coefficients are useful for testing for differences in relative abundance between fossil assemblages and their live source (Kidwell 2001). Here, Kendall's $\tau\left(r_{\tau}\right)$ rank correlation coefficient was used instead of Spearman $\left(r_{s}\right)$ because a different interdependence deviation and a higher reliability of closer ranks were expected (Sokal \& Röhlf 1995).

\section{RESULTS}

\section{Predation}

A total of 63 mussels were preyed upon by the crabs: 9 were killed and consumed by $H$. oregonensis, 3 by L. bellus, 12 by C. productus, 10 by C.magister, and the rest (29) by C. oregonensis (Table 1). Hemigrapsus nudus did not successfully prey on a mussel, although they tried. Most of the successful predation was achieved by crushing (Table 1) both mussel valves. The laboratory observations indicate that $M$. trossulus $>35 \mathrm{~mm}$ in size are safe from predation by the most common crab (H. oregonensis) in Argyle Creek.

In general, $H$. oregonensis attacks close to the middle of the mussel's commissure and leaves a zig-zag or serrated pattern (Fig. 3a and 3b) on both valves. Cancer oregonensis, whereas it also attacks the middle part of the mussel's commissure, tends to do more damage to one of the valves (Fig. 4a). Shells of some of the mussels killed by both species were damaged either on the anterior or posterior margin but far from the commissure (see damage comparison section). Because not all crab species killed

TABLE 1.

Type of damage (number of mussels) inflicted on Mytilus trossulus shells by different species of crab during successful predation. Note that Hemigrapsus nudus did not successfully prey on a mussel.

\begin{tabular}{lccccccc}
\hline \hline \multicolumn{1}{c}{ Species } & Nibbles \& Chips & Crushing & Crush \& Peel & Nibble & Nibble \& Crush & Nibble \& Peel & Peel \\
\hline Cancer magister & 0 & 10 & 0 & 0 & 0 & 0 \\
Cancer oregonensis & 0 & 9 & 2 & 8 & 1 & 4 \\
Cancer productus & 0 & 4 & 4 & 0 & 0 & 2 \\
Hemigrapsus oregonensis & 0 & 5 & 1 & 2 & 1 & 0 \\
Lophopanopeus bellus & 1 & 0 & 0 & 0 & 0 & 0 \\
Total & 1 & 28 & 7 & 10 & 2 & 1 \\
\hline
\end{tabular}


a

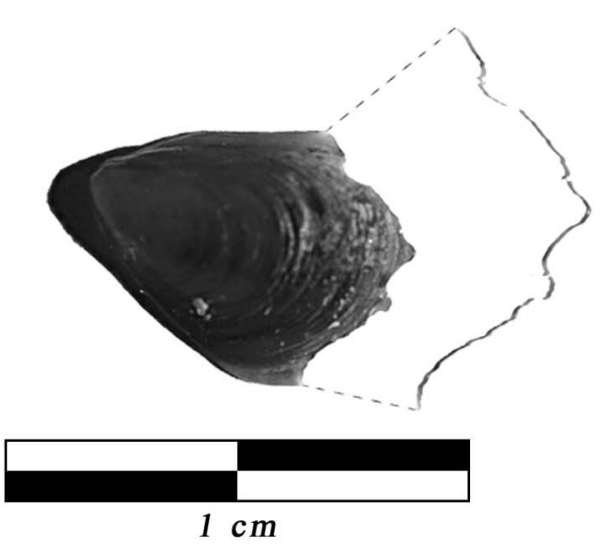

b

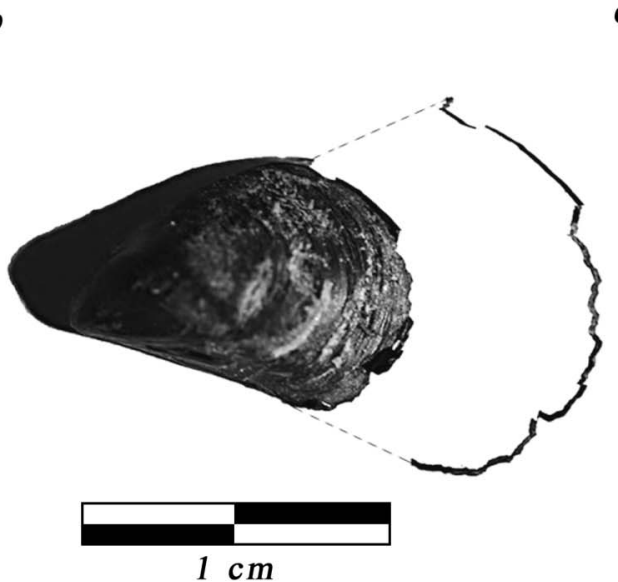

d

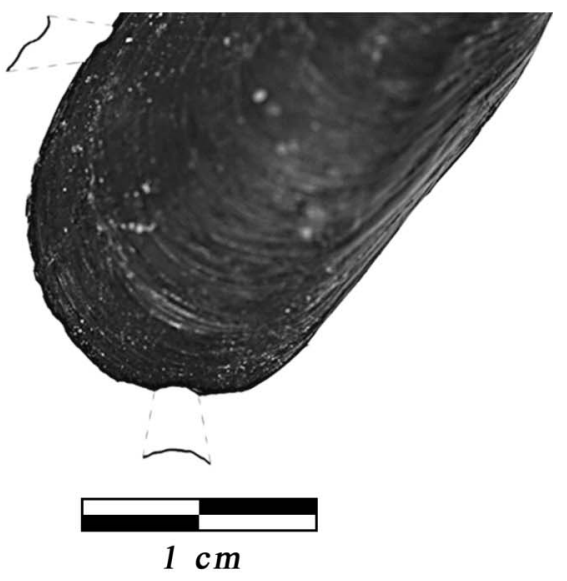

e
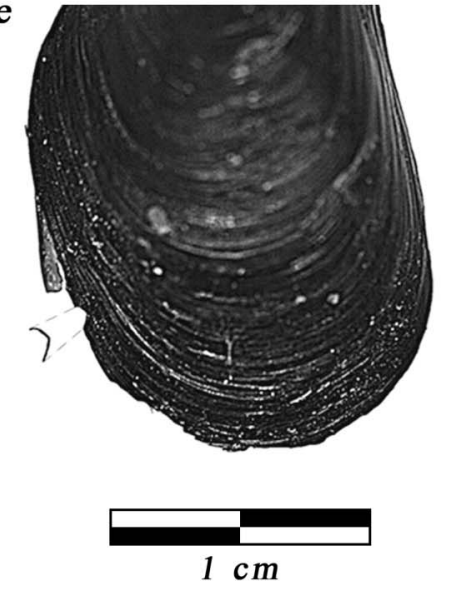

$f$

c
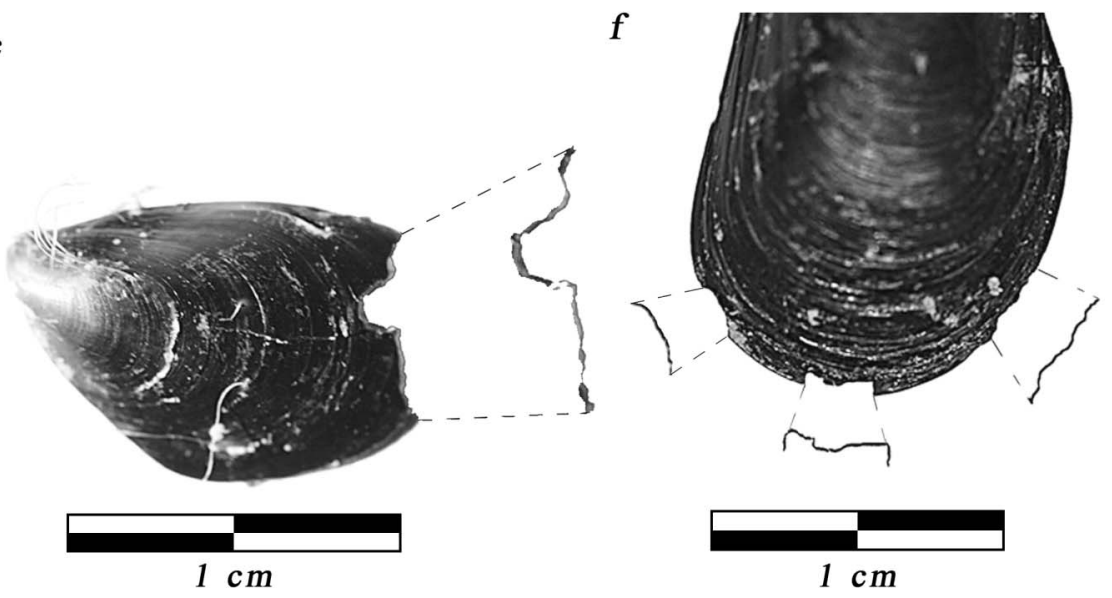

Figure 3. Breakage patterns in Mytilus trossulus shells: (a) predatory crab peeling, (b) predatory crab nibbling, (c) nibbles and chips by predatory crabs, (d) crescentic chips by trampling, (e) angular individual chip by trampling, and (f) series of echeloned angular chips by trampling. Scale bar in cm. In all cases (a to $f$ ) an outline of the marginal damage was increased 1.5 from its actual size.

enough prey, and because the number of individuals represented by most crab species was low, a quantitative or statistical comparison of mussel damage stereotypy among species was not possible. However, damage inflicted by each crab species was used to distinguish antemortem predatory damage from ante- and postmortem mechanical breakage (see next section).

From the field-collected information, a total of 530 mussels were found alive during the survey; the number of dead mussels was 222. As expected, the within-quadrat abundance of live and dead shells was highly correlated $\left(\mathrm{r}_{\tau}=0.68, \mathrm{~F}_{0.05(1,14)}=\right.$ $30.02, P=0.0001)$ indicating a significant live-dead agreement. In other words, if a quadrat had a large number of live individuals, it tended to have a large number of dead individuals.

Dead mussels at Argyle Creek numbered $\sim 40 \%$ of the live population. Further inspection of the 444 dead shells for predatory shell damage indicated that 6 individuals $(\sim 3 \%)$ were killed by muricid snails (based on the borehole morphology), and 110 mussels $(\sim 50 \%)$ perished from crab predation (see 

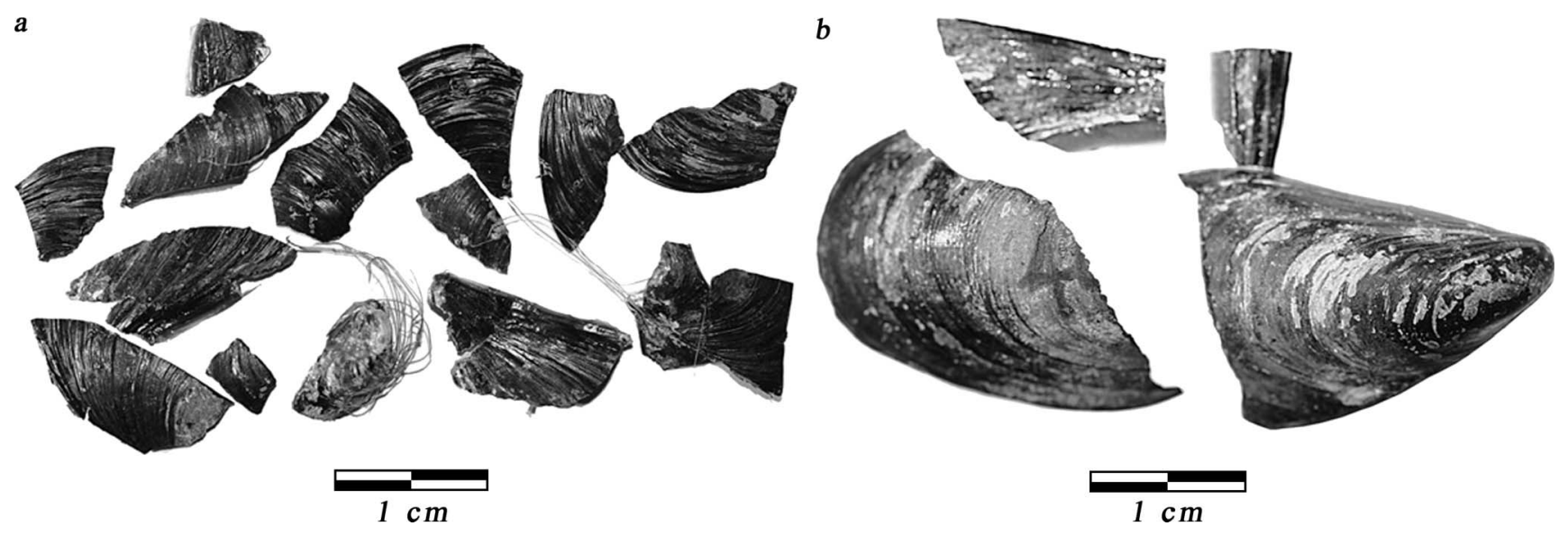

Figure 4. Fragmentation in Mytilus trossulus shells produced by: (a) predatory crushing and (b) trampling. Scale bar in cm.

damage comparison section). The cause of death for the remaining 106 mussels could not be determined. The reported percentage attributed to predation only accounts for those shells in which distinctive predatory damage was observed (see discussion).

\section{Damage Comparison}

Five types of damage were caused by crab predation: peels, nibbles, nibbles and chips, crushing, and fractured margins. In several instances a combination of more than one type occurred (Tables 1 and 2).

\section{Peels}

Deep adjacent chips along the shell margin with a characteristic zig-zag pattern (Fig. 3a) or an almost straight, scissorlike cut. Peeling damage varies from few $\mathrm{mm}$ to some $\mathrm{cm}$ along the commissure. Damage extends along either or both anterior or posterior margins. In contrast to nibbling, peeled damage penetrates more deeply into the shell, sometimes as much as $20 \mathrm{~mm}$.

\section{Nibbles}

Many adjacent chips along the shell margin result in an echelon or zig-zag pattern (Fig. 3b) though not as prominently as in peeling (see above). Nibbling tends to occur along several $\mathrm{cm}$ of either the anterior or posterior shell margin, but each chip along the nibble never exceeds a few $\mathrm{mm}$ in length. Each chip may penetrate one or two $\mathrm{mm}$ beyond the margin.

\section{Nibbles and Chips}

Chips are small (from a few $\mathrm{mm}$ to a $\mathrm{cm}$ ) concave indentations along the anterior or posterior margins (Fig. 3c). The indentations can extend for a few $\mathrm{mm}$ into the shell. Predatory chips occur in combination with nibbling along the shell's growing margin.

\section{Crushed}

Shell fragments, which vary in size and shape (Fig. 4a). Most fragments have at least two very sharp points. Fragments of shells crushed by predators are indistinguishable from fragments caused by trampling (Fig. 4b).

TABLE 2.

Type of damage inflicted on Mytilus trossulus shells by all different agents studied in the laboratory. The first number is the number of shells affected by a particular type of damage; the number within parentheses is the number of instances of a particular type of damage. Because many shells displayed more than one type or instance of damage, the sum of the number of shells or instances in each column exceeds the total number of shells damaged.

\begin{tabular}{|c|c|c|c|c|}
\hline Type of Damage & $\begin{array}{l}\text { Crab Predation } \\
\text { in Laboratory }\end{array}$ & Trampled & Tumbled-dead & Tumbled-live \\
\hline \multicolumn{5}{|l|}{ Diagnostic } \\
\hline Nibbles & $64(183)$ & $0(0)$ & $0(0)$ & $0(0)$ \\
\hline Nibbles and Chips & $2(2)$ & $0(0)$ & $0(0)$ & $0(0)$ \\
\hline Peels & $54(121)$ & $0(0)$ & $0(0)$ & $0(0)$ \\
\hline Angular chips & $0(0)$ & $4(15)$ & $0(0)$ & $0(0)$ \\
\hline Crescentic chips & $0(0)$ & $3(7)$ & $4(9)$ & $0(0)$ \\
\hline Slivered chips & $0(0)$ & $2(2)$ & $0(0)$ & $0(0)$ \\
\hline \multicolumn{5}{|l|}{ Not Diagnostic } \\
\hline Fractured margins & $48(73)$ & $13(36)$ & $1(1)$ & $0(0)$ \\
\hline Crushed & $74(274)$ & $7(15)$ & $0(0)$ & $0(0)$ \\
\hline Sum & $242(653)$ & $29(75)$ & $5(10)$ & $0(0)$ \\
\hline Total & $126(580)$ & $20(60)$ & $5(8)$ & $0(0)$ \\
\hline
\end{tabular}


No mechanical damage was detected on the 30 live-mussels after $100 \mathrm{~h}$ of tumbling. All individuals perished at $10 \mathrm{~h}$, and all tissues, except for the still-attached ligament in most of the larger individuals, disappeared after $100 \mathrm{~h}$. Lack of mechanical damage was also observed for the tumbled-dead shells, but a few (four) showed minor chipping-crescentic chips, see later-on the marginal area (Fig. 3d) after $1 \mathrm{~h}$ of tumbling (Fig. 5). Only one was fractured-fractured margin, see later-along the posterior area close to the umbo (Fig. 6a) the fracture appeared at $10 \mathrm{~h}$ and increased in length at $100 \mathrm{~h}$. A common result after $100 \mathrm{~h}$ of tumbling for live and dead-shells was a proportional (length, width, and thickness) reduction in size and a well-polished shell surface.

Five breakage patterns occurred because of trampling: crushing, crescentic chips, angular chips, fractured margins, and slivered chips.

\section{Crescentic Chips}

Semicircular chipped damage that extends no more than a $\mathrm{cm}$ along either anterior or posterior margin (Fig. 3d). The depth of the concave chips does not exceed $1 \mathrm{~cm}$. Chipping from trampling occurs without the nibbles caused by crab predation.

\section{Angular Chips}

Angular chips can occur individually leaving a squarecornered chip that never penetrates more than $1 \mathrm{~cm}$ in depth and extends only a few mm in length along the shell margin (Fig. $3 \mathrm{e}$ ); or as a series of chips along the shell margin, each of which is a few mm in length and depth. Echeloned chips can occur on either margin (Fig. 3f). Damage to the shell margin is not as extensive as in nibbling (Fig. 3b) or as in nibbling and chips (Fig. 3c). Sometimes damage leaves clear and sharply angular indentations of two or three $\mathrm{mm}$ in length, which are not scissorlike and therefore differ from damage caused by peeling. In these cases, the traces never form echelons, although they can be repetitive, forming a zig-zag pattern.

\section{Fractured Margins}

A line of breakage penetrating the shell from a few millimeters to a few centimeters; sometimes extending almost through the entire shell (Fig. 6a). Shell fragments may or may not be detached. Fracture lines tend to cut across growth lines

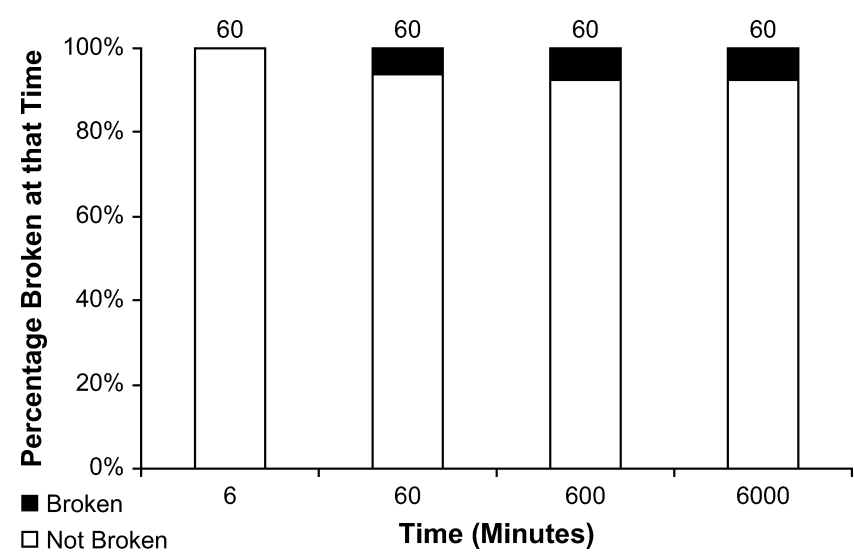

Figure 5. Dead-mussels (Mytilus trossulus) shell breakage (\%) after tumbling time. Numbers on top indicate number of tumbled-shells. at a high angle. In extreme cases, angular and sometimes triangular breakage along the margin penetrates up to several centimeters into the shell (Fig. 6b). Fractures typically cut across growth lines at a high angle. Detached fragments vary in size from millimeters to centimeters. Those cannot be distinguished from fragments generated by crabs during crushing (Fig. 4). Fractured margins are the most common damage resulting from trampling (Table 2).

\section{Slivered Chips}

Subtle breakage parallel or nearly parallel to the shell margin (Fig. 7), extending from a few millimeters to a centimeter.

The percentage of shells affected by predation under laboratory conditions and trampling was similar, but differed from predation in the field and tumbling. No breakage occurred with the tumbled-live mussels (Fig. 8).

Twenty-five shells were damaged by trampling or tumbling (see totals in Table 2). Of these 25 shells, 20 bore the distinctive angular chips, crescentic chips or slivered chips found only in mechanically damaged shells. Some of these 20 shells showed more than one type of distinctive damage. Thus, $20(80 \%)$ of the 25 shells damaged by trampling or tumbling could be correctly assigned to a source of damage. One-hundred and twenty-six shells were damaged by crab predation. Ninety-two of these shells showed the peels, nibbles, and nibbles and chips that are diagnostic of crab predation. Thus, $92(73 \%)$ of the 126 preyedon shells could be correctly assigned to a source of damage.

Of the $151(25+126)$ shells that were damaged by predation, trampling or tumbling; $112(74 \%$ [20 +92]) showed damage that was diagnostic of either predatory or mechanical (trampling or tumbling) damage. Shells that were damaged by predation tended to exhibit more instances of damage (653 instances of damage on 126 shells for an average of 5.2 instances per shell) than shells that were damaged by mechanical means ( 85 instances on 25 shells, for an average of 3.4 instances per shell).

\section{DISCUSSION}

\section{Identification of Damage}

Traces identified as nibbles and chips in this study can be compared with traces called "arcuate" or "horseshoe" by Checa (1993), and later categorized as "embayed" by Alexander \& Dietl (2001). These studies focused on repair scars attributed to burrowing (Checa 1993) or all types of shell breakage (Alexander \& Dietl 2001). A major difference from the nibbles and chips damaged-shells is the rugged surface (Fig. 3c), which is absent on the arcuate (Plate $1 \mathrm{k}$ and 11 in Checa 1993) and embayed (Figs. 3g and 3k in Alexander \& Dietl 2001) shells, where the repaired area is often smooth.

Nibbles are probably the easiest damage to recognize because of their extension along the shell margin (Fig. 3b). Only two (Plate 1d and 1k) of the damaged shells from burrowing reported by Checa (1993) are comparable to the traces left by predatory nibbling. However they clearly differ because of the contiguous penetration pattern-referred as cluster breaks by Checa (1993) - into the shell when damaged by burrowing.

Predatory damage from peeling might be the hardest to distinguish from patterns caused by other causes, particularly when compared with abraded or serrated repaired damage 

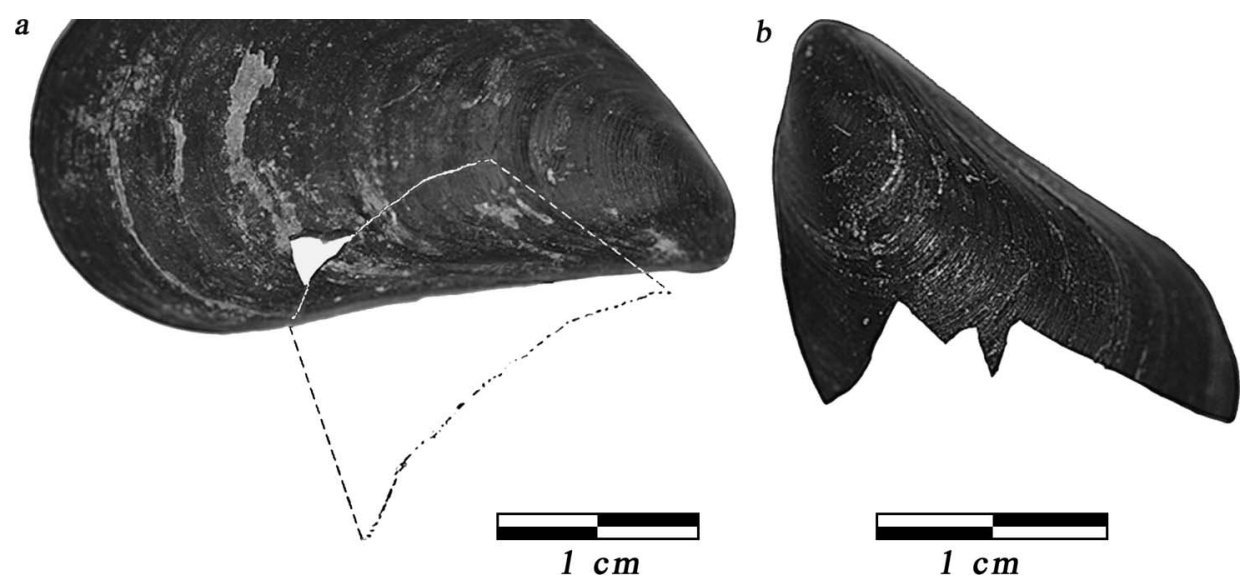

Figure 6. Mechanical breakage patterns in trampled Mytilus trossulus shells: (a) fracture line and (b) greatly fragmented fracture margins. Scale bar in $\mathrm{cm}$. For the fracture line (a) an outline of the damage was increased 1.5 from its actual size.

resulting from isolated or aligned arcuate breakage from burrowing (Plate 1i in Checa 1993). However, peeled damage typically penetrates deeply into the shell (Fig. 3a), whereas the arcuate breakage observed by Checa (1993) penetrates only a few $\mathrm{mm}$. Furthermore, in other shells damaged by burrowing (Plate 1e and $1 \mathrm{j}$ in Checa 1993), the repair scar tends to have a contiguous penetration pattern into the shell.

The lack of damage to tumbled-live shells (Fig. 8), and the low frequency of damage $(\sim 8 \%)$ recorded by the tumbled-dead shells (Fig. 5 and 8) are good news for distinguishing damage from antemortem biological crab predation and ante- and postmortem mechanical breakage. The minor damage occurring as a result of tumbling is easily distinguished from damage caused by crab predation.

The results of the tumbling experiment are even more useful because they suggest that damage to the dead-shells in Argyle Creek is most likely caused by either trampling or crab predation. Argyle Creek is relatively protected from waves thus crushing by rocks is probably not a major cause of breakage except during big storms. Breakage during storms cannot be completely ruled out because no sampling was performed before and after such events. However, cluster breaks - repair damage displaying an oblique or radial arrangement of the affected margin over a length of time - around growth increments were not observed in the majority of the individuals. Such damage is, according to Checa (1993), caused during storms and repaired during subsequent growth. The progressive rounding associated with shell abrasion from high-energy impacts on rocks (Zuschin et al., 2003) was not observed in Argyle Creek. In fact, Cate \& Evans (1994) suggest that predation rather than natural mechanical breakage is the cause of most shell fragmentation in low-energy environments. In any event, the paleoecological and taphonomic value of fragments is limited because of the difficulty of distinguishing different sources of breakage and fragmentation (Vermeij 1983a, Cate \& Evans 1994). Furthermore, Lescinsky et al. (2002) suggest that biostratinomic (i.e., postmortem, preburial) fragmentation is quantitatively unimportant during the first two years of exposure, and is restricted to chipping at the shell's margin.

The lack of mechanical damage on the tumbled-live shells, but low frequency of mechanical damage presence ( $8 \%$ broken) on the dead ones (Fig. 8) might be explained by differences in the shell's time since death (sensu Kidwell \& Bosence 1991). The shell's mechanical strength and elasticity decreases as shells dry out because the organic matrix of the shells decays (Glover \& Kidwell 1993); new (recently dead) shells are less sensitive to breakage than older shells (Currey 1980). Degradation of the organic matrix has been used to explain strength decreases in shells of Mytilus edulis Linnaeus, 1758, immersed in water for seven weeks (Zuschin \& Stanton 2001).

From the tumbled-dead shells that were broken, only one $(\sim 1.6 \%)$ was fractured along the posterior area close to the umbo (Fig. 6a), whereas the rest (four) showed minor chipping along the margins area (Fig. 3d). A similar breakage pattern

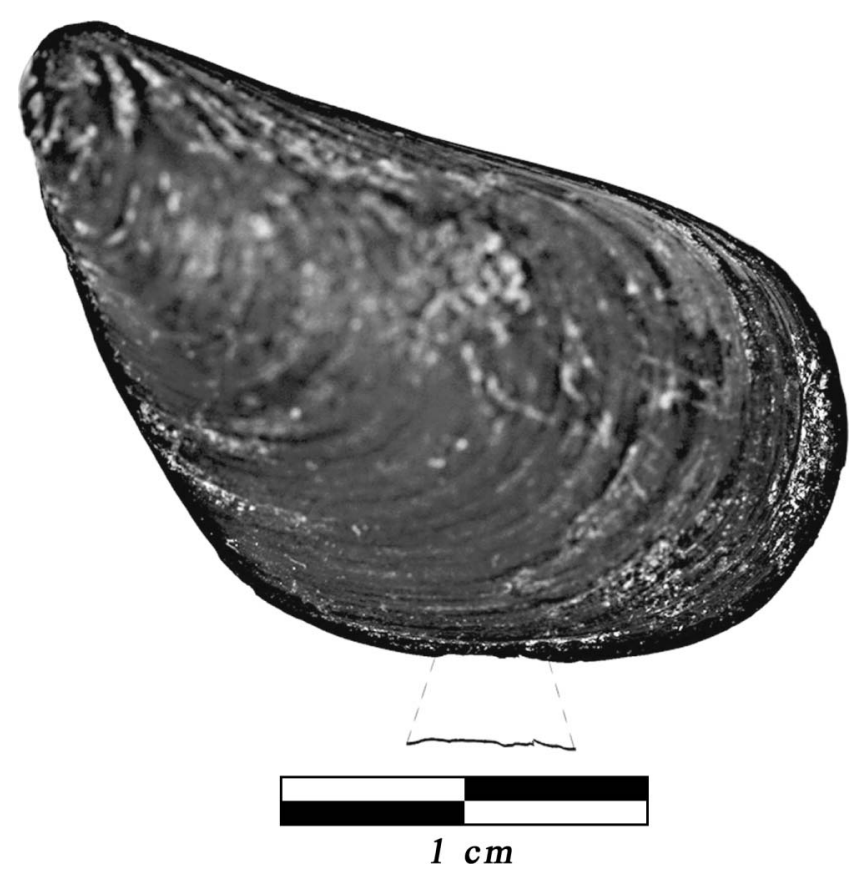

Figure 7. Slivered chip breakage patterns in trampled Mytilus trossulus shells. Scale bar in $\mathrm{cm}$. Outline of the marginal damage was increased 1.5 from its actual size. 


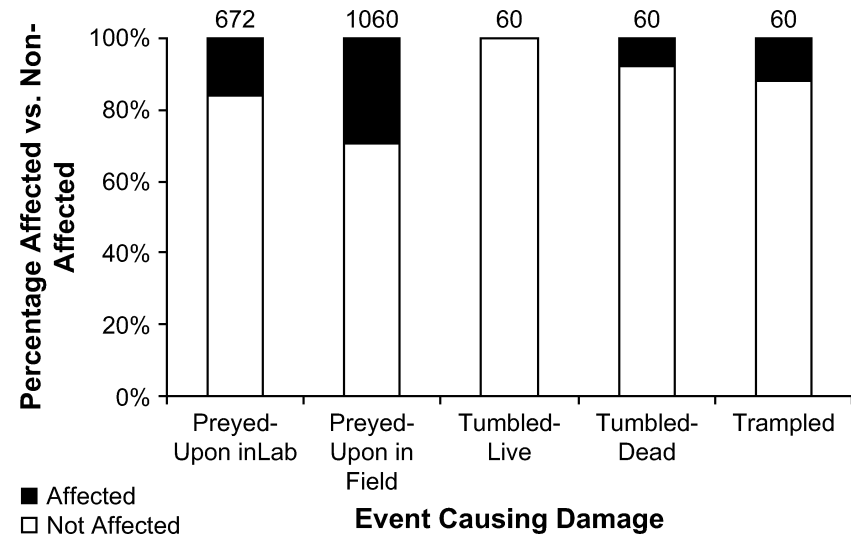

Figure 8. Mytilus trossulus shell damage (\%) caused during each experiment and from field survey. Numbers on top indicate number of shells used in each experiment and total counted in the field, respectively.

was also observed for shells of Mulinia coloradoensis Dall, 1894, where only $2 \%$ of the tumbled material showed marginal damage similar to that caused by crab predation (CintraBuenrostro \& Flessa 2004, Cintra-Buenrostro et al. 2005). Thus, tumbling barrel experiments with Mytilus trossulus indicate that postmortem physical damage to the shell margin is distinctively different from damage caused by crab predation.

Although all natural conditions are not duplicated by tumbling experiments, Kuenen (1956) indicated that the abrasion caused by sediments was successfully reproduced. In fact, abrasion on bivalve shells is faster in rolling barrels than in the surf zone (Driscoll 1967). Although no significant breakage on either M. trossulus (this study) or Mulinia coloradoensis (CintraBuenrostro \& Flessa 2004, Cintra-Buenrostro et al., 2005) was detected during tumbling, other mollusc and brachiopod skeletons have broken up during similar experiments (Chave 1964, Driscoll \& Weltin 1973, Oji et al. 2003, DeFreitas-Torello 2004). Mytilus spp. has proven to be a very durable shell (Chave 1964). Breakage during abrasion by tumbling with chert pebbles for $\sim 183 \mathrm{~h}$ at $30 \mathrm{rpm}$ resulted mostly from particle-against-particle crushing (Chave 1964). In another experiment, destruction of M. edulis shells was less than $50 \%$ after $100 \mathrm{~h}$ of tumbling (DeFreitas-Torello 2004).

Shells tumbling with sediments yielded broken mollusc valves with angular margins, which in shallow-marine deposits could be mistaken for evidence of durophagous predation because neither currents nor wave agitation produce shells with angular margins (Oji et al. 2003). However, if subsequent abrasion or bioturbation by boring organisms (Cadée 1994) occurs, predatory fragments will be similar to those resulting from transportation or tumbling (Stanton \& Nelson 1980).

The approaches taken here allowed proper identification of the source of damage inflicted to the mussel shells in $\sim 75 \%$ of the cases, suggesting that it is feasible to clearly distinguish mechanical from biological damage. Crushed fragments and fractured margins are not diagnostic, whereas peels, nibbles, nibbles and chips, angular chips, crescentic chips, and slivered chips are diagnostic. The good news is that crab predation and mechanical breakage usually result in distinctive shell damage. The bad news is that $\sim 25 \%$ of the damage is not diagnostic; it could be from either cause. If $M$. trossulus crab damage plus mechanical damage is similar to that of other species in the fossil record, the use of these criteria could help distinguish between antemortem predatory crab damage and ante- and postmortem mechanical damage.

The best approach may be to use the criteria used here, and, when faced with nondiagnostic damage identification, take into account the difference in the average number of instances occurring per damage type. The latter is a strong criterion that could eliminate a large number of confusing instances of shell damage. Although more experimental and field studies are needed, adding this extra criterion may provide a solution in some cases.

Application of these criteria might overestimate predation because not all causes of damage result in the same distinctive breakage pattern all the time, because many other factors that cause breakage were not studied (see also words of caution section), and because some crabs are known to attack empty shells (LaBarbera 1981, Walker \& Yamada 1993). Moreover, trampling in Argyle Creek might be more frequent than reported here, where only one set of experiments was performed.

To summarize, the combined field and laboratory approach used here allowed the proper identification of shell damage resulting from crab predation in $73 \%$ of the cases, and the proper identification of shell damage resulting from trampling in $80 \%$ of the cases. The overall proper identification of shell damage was $74 \%$. In other words - excluding crushed fragmentsif a sample consisted of 100 shells with 50 showing the type of damage found in the experiments with predatory crabs, 10-13 of those 50 crab-damaged shells were probably damaged by physical processes. Thus, proper identification of crab predation in dead shells is possible in this commercially important genus. This practice may prove valuable in studies of trophic interactions in modern environments. If a latitudinal gradient in shell-crushing predation exists, it should be possible to recognize it on the basis of analyses of dead shells.

It is also likely that traces of crab predation on mussel shells from fossil and subfossil environments can be recognized correctly, especially when also using other indicators diagnostic of particular predators (reviewed in Zuschin et al. 2003, p. 59). Extrapolation to other taxa might be possible but should be confirmed by field and laboratory studies. Of course, the use of the anthropogenic trampling per se in the fossil record is not important for a paleontologist, nonetheless the present study allowed comparison and distinction from two sources of damage (biological by crab predation and mechanical by tumbling and trampling) to the mussel shells. Thus the point to estimate the mechanical source of damage, independently of what caused (e.g., trampling by humans, or rocks crushing the shells) seems possible.

\section{Predation}

Shell damage on mussels killed by H. oregonensis was similar to that on ones killed by $C$. oregonensis. This suggests that it might not be possible to distinguish the two predators from the damage that they cause to shells, particularly when crabs similar in size are used. Hemigrapsus oregonensis can reach up to $49 \mathrm{~mm}$ in carapace width (Telnack \& Phipps 2005), and the maximum carapace width reported by Kozloff (1973) for Cancer oregonensis is $40 \mathrm{~mm}$. Nevertheless, differences in crab chelae affect both predation method (i.e., crushing vs. peeling) and success 
rates (West \& Cohen 1991). A wide range of mussel opening techniques, which varied according to prey size and shell strength, were reported by Zipser \& Vermeij (1978). Carcinus maenas (Linnaeus, 1758) exhibited different techniques also related to prey size and strength (Elner 1978). Within the San Juan Archipelago, H. nudus, Cancer oregonensis, C. productus and Lophopanopeus bellus switched from crushing to peeling as prey size increased (Behrens-Yamada \& Boulding 1998). Although stereotypical shell damage might not occur, identification of the predator may be likely when other evidence (e.g., microhabitat or bathymetric distribution) can be associated with the death assemblage that includes the damaged shells.

A mollusc's protection against peeling is primarily because of its shell size and thickness (Vermeij et al. 1980). The laboratory observations indicate that $M$. trossulus $>35 \mathrm{~mm}$ in size are safe from predation by the most common crab (H. oregonensis) in Argyle Creek. If this is the case, the grapsids can still have lethal effects on the $M$. trossulus population by attacking the vulnerable juvenile stages. Behrens-Yamada \& Boulding (1996) reported that in the mid and upper intertidal zone on the northeastern Pacific the abundance of both generalist predators (H.nudus and H. oregonensis), and Cancer productus (a mollusc specialist) is high enough to affect other molluscan populations.

It is worth noting that the unique conditions of Argyle Creek allow predators to feed continuously through the tide cycle. Despite this fact, no cancrids were observed during any of the visits (although all visits were during lowest low tide). A considerable number (220) of dead shells collected at Argyle Creek show signs of crab predation, suggesting that under natural conditions either the crabs studied here are capable of consuming many mussels or that other durophagous crabs visit the Creek during high tide. Nevertheless, such an upper limit to the size-refugia might be high because at Argyle Creek, $H$. oregonensis are able to consume many other prey itemsincluding algae - and the energy investment required to either nibble, peel or crush a mussel of any size can be avoided or compensated by prey-switching. Because crab predation on intertidal mussels is inversely correlated with tidal flow (Leonard et al., 1999), both the size-refuge and the mussels' destiny changes during high tides, when bigger crabs (i.e., C. magister) enter the Creek and feast on available bivalves. Moreover, predation rates on wave protected shores at or near Friday Harbor Laboratories (FHL) on San Juan Island by $H$. nudus, L. bellus, C. oregonensis, and C. productus on Littorina sitkana Philippi, 1845, ranged from $2 \%$ to $77 \%$ per high tide period (Behrens-Yamada \& Boulding 1996).

The peeled shells in the Creek can be safely attributed (74\% of the time) to crab predation as demonstrated by the experimental approach used here. Although fishes might also prey on the mussels, evidence suggests that their contribution may not be high because the characteristic shell damage inflicted by the Pile Perch (Damalichthys vacca [Girard]) was not produced on shells crushed by the crabs, nor on specimens crushed by rocks in the San Juan Archipelago (Behrens-Yamada \& Boulding 1996).

Surprisingly enough, $H$. nudus did not prey on any mussel despite the fact that they successfully peeled some mussels during the pilot experiment, and have successfully peeled small specimens of the gastropod Littorina sitkana within the FHL facilities under similar conditions as the ones used in the present study (i.e., Behrens-Yamada \& Boulding 1998). Those authors argued that $H$. nudus are poor peelers because their weak claws lack sharp, shearing tips. However, its congeneric (H. oregonensis) shares similar claws and even though smaller in overall body size was successful at predation under laboratory conditions.

\section{Words of Caution}

The estimated $50 \%$ crab predation rate at Argyle Creek on the mussels can be a misleading figure because only dead shells were used to estimate predation rates and only at one time. Because no subsequent surveys were performed to estimate Argyle Creek's mussel population size, the 50\% figure represents only a snapshot in time. Seasonal differences in chipped or crushed shells percentages occur with seasonal differences in predation (Beal et al. 2001). Most of the time, abundance patterns are based on organism surveys over short time scales, which may provide little insight into the temporal changes characteristic of benthic assemblages (Gray 1981). Thus, extrapolation from the present research to larger areas is not yet justified. More work is required over a larger area and over a longer period.

Peeling frequencies alone underestimate rates of crab predation, particularly with those crabs that are able to switch their prey-handling strategy.

Before extrapolation to the fossil record of damaged shells, further testing of tumbled and trampled shells is needed. Experiments and field studies should vary densities of sediment and valves, encrusted versus nonencrusted, valves with borers present or absent, and they should replicate higher energy environments.

\section{CONCLUSION}

Crushing was the most common mechanism used by crabs for successful predation on $M$. trossulus. Species-level stereotypic damage could not be detected, but predation by crabs did result in distinctive damage to shells. Five types of damage were inflicted by crab predation: crushing, peels, nibbles, nibbles and chips, and fractured margins.

No mechanical damage was detected on the tumbled-live mussels after $100 \mathrm{~h}$. Mechanical damage on tumbled-dead mussels after $100 \mathrm{~h}$ was minor. A common result for tumbledlive and tumbled-dead shells was a proportional (in length, width, and thickness) size reduction and a well-polished surface after $100 \mathrm{~h}$.

Five breakage patterns occurred in trampled shells: crushing, crescentic chips, angular chips, fractured margins, and slivered chips. Greatly fragmented fractured margins are the most common damage resulting from trampling. Fragments of shells crushed by predators are indistinguishable from fragments caused by trampling.

Eighty percent of the shells damaged by trampling exhibited damage distinctly different from the damage caused by predation. Seventy-three percent of the shells damaged by predation exhibited damage distinctly different from the damage caused by trampling. Overall, application of these criteria results in a correct assignment of damage in $74 \%$ of the shells. Thus, in Mytilus trossulus at least, the cause of damaged shells can be assigned with confidence in $\sim 75 \%$ of the cases; that 
is in three out of four individuals. This result is potentially good news for the use of marginal damage as an indicator of predation in the fossil record.

\section{ACKNOWLEDGMENTS}

The author thanks M. Kowalewski and L. Leighton for a great course and constructive criticism on the manuscript, R. Krause and J. Stempien for an extensive logistic support, all the participants of the predator-prey interaction Summer 2004
Course of Friday Harbor Laboratories (FHL) for all their friendship and support and all the personnel of FHL for making this happen, K. Flessa, W. Shaw, FHL and the Dept. of Geosciences (University of Arizona) for financial aid. Comments from K. Flessa, M. Zuschin, R. Brusca, A. Cohen, M. A. Téllez-Duarte, and one anonymous reviewer, improved the manuscript. This paper is dedicated to the memory of my great friend R. Fromm-Rihm who unfortunately passed away during my time at FHL. This paper is publication 51 of the Centro de Estudios de Almejas Muertas.

\section{LITERATURE CITED}

Alexander, R. R. \& G. P. Dietl. 2001. Shell repair frequencies in New Jersey bivalves: a recent baseline for tests of escalation with Tertiary, Mid-Atlantic congeners. Palaios 16:354-371.

Alexander, R. R. \& G. P. Dietl. 2005. Non-predatory shell damage in Neogene Western Atlantic deep-burrowing bivalves. Palaios 20:280-295

Allmon, W. D., J. C. Nieh \& R. D. Norris. 1990. Drilling and peeling of Turritelline gastropods since the Late Cretaceous. Paleontology 33:595-611.

Beal, B. F., M. R. Parker \& K. W. Vencile. 2001. Seasonal effects of intraspecific density and predator exclusion along a shore-level gradient on survival and growth of juveniles of the Soft-Shell Clam, Mya arenaria L. J. Exp. Mar. Biol. Ecol. 264:133-169.

Behrens-Yamada, S. \& E. G. Boulding. 1996. The role of highly mobile crab predators in the intertidal zonation of their gastropod prey. J. Exp. Mar. Biol. Ecol. 204:59-83.

Behrens-Yamada, S. \& E. G. Boulding. 1998. Claw morphology, prey size selection and foraging efficiency in generalist and specialist shell-breaking crabs. J. Exp. Mar. Biol. Ecol. 220:191-211.

Boulding, E. G. 1984. Crab-resistant features of shells of burrowing bivalves: decreasing vulnerability by increasing handling time. $J$. Exp. Mar. Biol. Ecol. 76:201-223.

Cadée, G. C. 1994. Eider, Shelduck, and other predators, the main producers of shell fragments in the Wadden Sea: palaeoecological implications. Palaeontology 37:181-202.

Cate, A. S. \& I. Evans. 1994. Taphonomic significance of the biomechanical fragmentation of live molluscan shell material by a bottom feeding fish (Pogonias cromis) in Texas coastal bays. Palaios 9:254-274.

Chave, K. E. 1964. Skeletal durability and preservation. In: J. Imbrie \& N. Newell, editors. Approaches to paleoecology. New York: John Wiley and Sons. pp. 377-387.

Checa, A. 1993. Non-predatory shell damage in recent deep endobenthic bivalves from Spain. Palaeogeogr. Palaeoclimatol. Palaeoecol. 100:309-331.

Cintra-Buenrostro, C. E. \& K. W. Flessa. 2004. Cavidades, mordiscos y peladas: herramientas para determinar la importancia trófica de una especie en desvanecimiento dentro del Delta del Río Colorado, México. Ciencia y Mar 8:3-19.

Cintra-Buenrostro, C. E., K. W. Flessa \& G. Avila-Serrano. 2005. Who cares about a vanishing clam? Trophic importance of Mulinia coloradoensis inferred from predatory damage. Palaios 20:296-302.

Cohen, J. 1988. Statistical power analysis for the behavioral sciences, 2nd ed. New Jersey: Lawrence Erlbaum Associates, Publishers. 567 pp.

Currey, J. D. 1980. Mechanical properties of the mollusc shell. Symp. Soc. Exp. Biol. 34:75-97.

DeFreitas-Torello, F. 2004. Tafonomia experimental do fóssil vivo Bouchardia rosea (Brachiopoda, Terebratellidae) e suas aplicações em paleontologia. PhD. Thesis. University of Sao Paulo. 143 pp.
Driscoll, E. G. 1967. Experimental field study of shell abrasion. J. Sed. Petrol 37:1117-1123.

Driscoll, E. G. \& T. P. Weltin. 1973. Sedimentary parameters as factors in abrasive shell reduction. Palaeogeogr. Palaeoclimatol. Palaeoecol. 13:275-288.

Elner, R. W. 1978. The mechanics of predation by the shore crab, Carcinus maenas (L.), on the edible mussel, Mytilus edulis L. Oecologia 36:333-344.

Glover, C. P. \& S. M. Kidwell. 1993. Influence of organic matrix on the post-mortem destruction of molluscan shells. J. Geol. 101:729747.

Gray, J. S. 1981. The ecology of marine sediments. Cambridge: Cambridge University Press.

Kelley, P. H., M. Kowalewski, \& T. A. Hansen (Eds.). 2003. Predatorprey interactions in the fossil record. New York: Kluwer Academic

Kidwell, S. M. 2001. Preservation of species abundance in marine death assemblages. Science 294:1091-1094.

Kidwell, S. M. \& D. W. J. Bosence. 1991. Taphonomy and timeaveraging of marine shelly faunas. In: P. A. Allison \& D. E. G. Briggs, editors. Taphonomy releasing the data locked in the fossil record. New York: Plenum Press. pp. 115-209.

Kowalewski, M. \& P. H. Kelley (Eds.). 2002. The fossil record of predation. Paleontol. Soc. Papers, USA. 8:1-398.

Kozloff, E. N. 1973. Seashore life of Puget Sound, the Strait of Georgia, and the San Juan Archipelago. Seattle, WA: University of Washington Press. 282 pp

Kuenen, P. H. 1956. Experimental abrasion of pebbles I. Wet sandblasting. Leidse Geol. Mededel 20:131-137.

LaBarbera, M. 1981. The ecology of Mesozoic Gryphaea, Exogyra, and Ilymatogyra (Bivalvia: Mollusca) in a modern ocean. Palaeobiology 7:510-526.

Lawton, P. \& R. N. Hughes. 1985. Foraging behavior of the crab Cancer pagurus feeding on the gastropods Nucella lapillus and Littorina littorea: comparisons with optimum foraging theory. Mar. Ecol. Prog. Ser. 27:143-154

Lazo, D. G. 2004. Bivalve taphonomy: testing the effect of life habits on the shell condition of the Littleneck Clam Protothaca (Protothaca) staminea (Mollusca: Bivalvia). Palaios 19:451-459.

Leonard, G. H., M. D. Bertness \& P. O. Yund. 1999. Crab predation, waterborne cues, and inducible defenses in the blue mussel, Mytilus edulis. Ecology 80:1-14

Lescinsky, H. L., E. Edinger \& M. J. Risk. 2002. Mollusc shell encrustration and bioerosion rates in a modern epeiric sea: taphonomy experiments in the Java Sea, Indonesia. Palaios 17:171-191.

Oji, T., C. Ogaya \& T. Sato. 2003. Increase of shell-crushing predation recorded in fossil shell fragmentation. Paleobiology 29:520-526.

Sokal, R. R. \& F. J. Röhlf. 1995. Biometry, 3rd ed. New York: W.H. Freeman and Company. $887 \mathrm{pp}$.

Stanton, R. J., Jr. \& P. C. Nelson. 1980. Reconstruction of the trophic web in paleontology: community structure in the Stone City Formation (Middle Eocene, Texas). J. Paleontol. 54:118135 . 
Telnack, J. \& M. Phipps. 2005. Intertidal marine invertebrates of the Puget Sound. Available at: http://www.nwmarinelife.com/ htmlswimmers/h_oregonensis.html Date accessed Oct. 12, 2005.

Underwood, A. J. 1997. Experiments in ecology. United Kingdom: Cambridge University Press. 504 pp.

Vermeij, G. J. 1983a. Shell-breaking predation through time. In: M. J. Tevesz \& P. Mc Call, editors. Biotic interactions in recent and fossil benthic communities. New York: Plenum Press. pp. 649-699.

Vermeij, G. J. 1983b. Traces and trends of predation, with special reference to bivalved animals. Palaeontology 26:455-465.

Vermeij, G. J. 1987. Evolution and escalation: an ecological history of life. New Jersey: Princeton University Press. 527 pp.

Vermeij, G. J., E. Zipser \& E. C. Dudley. 1980. Predation in time and space: peeling and drilling in terebrid gastropods. Paleobiology 6:352-364.
Walker, S. E. \& S. B. Yamada. 1993. Implications for the gastropod fossil record of mistaken crab predation on empty mollusc shells. Palaeontology 36:735-741.

West, K. \& A. S. Cohen. 1991. Morphology and behavior of crabs and gastropods from Lake Tanganyika, Africa: implications for lacustrine predator-prey coevolution. Evolution Int. J. Org. Evolution 45:589-606.

Zipser, E. \& G. J. Vermeij. 1978. Crushing behavior of tropical and temperate crabs. J. Exp. Mar. Biol. Ecol. 31:155-172.

Zuschin, M., M. Stachowitsch \& R. J. Stanton, Jr. 2003. Patterns and processes of shell fragmentation in modern and ancient marine environments. Earth-Sci. Rev. 63:33-82.

Zuschin, M. \& R. J. Stanton, Jr. 2001. Experimental measurement of shell strength and its taphonomic interpretation. Palaios 16:161170 . 